\title{
PENGARUH PSIKOEDUKASI TERHADAP DEPRESI POSTPARTUM PADA IBU PRIMIPARA
}

\author{
Awaludin Jahid Abdilah*Septiyani Eka Putri**
}

\begin{abstract}
ABSTRAK
Ibu Postpartum yang tidak berhasil menyesuaikan diri dengan peran barunya akan mengalami gangguan emosional seperti depresi pasca persalinan (DPP). Depresi pasca persalinan (DPP) adalah suatu depresi yang ditemukan pada perempuan setelah melahirkan, yang terjadi dalam kurun waktu 4 (empat) minggu. Rumusan masalah yang diangkat dalam penelitian ini adalah tentang pengaruh psikoedukasi dalam mengatasi depresi postpartum pada ibu bersalin di Wilayah Kerja Puskesmas Plered Kabupaten Cirebon tahun 2016. Sehingga diharapkan dari penelitian dapat mengetahui depresi ibu postpartum sebelum dan sesudah dilakukan Psikoedukasi serta untuk mengetahui ada tidaknya penurunan tingkat depresi setelah dilakukan Psikoedukasi. Penelitian ini berjenis one-group pretest-posttest design yaitu kelompok subjek diobservasi sebelum dilakukan intervensi, kemudian di observasi lagi setelah dilakukan intervensi. Populasi dalam penelitian ini adalah seluruh ibu postpartum primipara berjumlah 24 orang yang berada di wilayah kerja puskesmas Plered pada bulan Febuari tahun 2016 dengan usia post partum 29 hari - 42 hari. Dalam mengambil sampel untuk diteliti, menggunakan teknik total populasi yaitu seluruh dari populasi dijadikan sampel penelitian. Gambaran depresi ibu postpartum primipara sebelum diberikan Psikoedukasi dari 24 responden menunjukan bahwa responden dengan depresi ringan sebanyak 12 responden 50.0\%). Dan ibu primipara sesudah diberikan Psikoedukasi dari 24 responden menunjukan bahwa tingkat depresi ringan sebanyak 10 responden $(41.7 \%)$. Berdasarkan hasil uji T-Test Pengaruh Psikoedukasi Terhadap Depresi Postpartum primipara yaitu dengan nilai $p$ value 0.016 sehingga dapat disimpulkan bahwa terjadi penurunan tingkat depresi setelah dilakukan Psikoedukasi pada ibu postpartum primipara di Wilayah Kerja Puskesmas Plered Kabupaten Cirebon Tahun 2016.
\end{abstract}

Kata kunci : ibu postpartum, primipara, psikoedukasi

\begin{abstract}
Postpartum mothers who did not manage to adjust to his new role will experience emotional disorders such as depression postpartum (DPP). Postpartum depression (DPP) is a depression that found in women after giving birth, which occurred within a period of four (4) weeks. The formulation of the issues raised in this study is on the influence of psycho-education in overcoming postpartum depression in mothers giving birth at Puskesmas Plered expected 2016.Sehingga Cirebon year of study can determine maternal postpartum depression before and after psychoeducation as well as to determine whether there is a decrease in the level of depression after psychoeducation. This research was a one-group pretest-posttest design is a group of subjects was observed before the intervention, and then observed again after the intervention. The population in this study were all post partum primiparous mother totaling 24. That was in the working area of Puskesmas Plered in February 2016 human premises postpartum 29 days - 42 days. In taking the sample to be tested, using the technique of total population of the entire study population sampled. Overview of maternal depression postpartum primipara before given psychoeducation of 24 respondents showed that respondents with mild depression were 12 respondents (50.0\%). And primiparous mothers after given Psikoediukasi of 24 respondents, shows that the level of mild depression as much as 10 respondents (41.7\%). Based on the test results of T-Test Effects of Postpartum Depression PsikoedukasiTerhadap primiparas ie with $\mathrm{p}$ value 0.016 thus it can be concluded decreased levels of depression after psychoeducation maternal postpartum primiparous in Wilayah Cirebon Kerja Puskesmas Plered 2016.
\end{abstract}

Keywords: post partum mothers, primiparous psychoeducation.

\footnotetext{
* Staf Pengajar Program Studi S1 Keperawatan STIKes Cirebon

** Alumni PSIK STIKes Cirebon Lulus Tahun 2016
} 


\section{PENDAHULUAN}

Persalinan merupakan proses alamiah yang dialami oleh setiap wanita. Berbagai reaksi ibu setelah melahirkan akan mempengaruhi sikap, perilaku dan tingkat emosional. Tekanan psikologis setelah persalinan merupakan gejala emosional dan perasaan dimana seseorang merasa murung, tidak bisa tidur, kelelahan fisik yang berlebihan, dan tidak mengetahui apa yang bisa dilakukan atas peranannya yang baru. ${ }^{1}$

Tekanan psikologis setelah persalinan mempunyai beberapa gejala antara lain gejala fisik seperti tidak dapat tidur, tidur berlebihan, tidak dapat berpikir jernih, merasa dikekang oleh suatu keadaan dan tidak dapat keluar dirinya, serta merasa lelah dan gerak geriknya menjadi lamban. Emosi yang positif dan hubungan kasih sayang akan memperlihatkan pengaruh orang tua terhadap pemeliharaan anak. ${ }^{1}$

Pengkajian pada ibu dari aspek psikologis merupakan dasar persiapan ibu dalam peran barunya untuk dilaksanakan. Secara teoritis seorang wanita setelah persalinan (post partum) pasti mengalami gangguan psikologis (Maternal Blues), hal ini dipengaruhi oleh perubahan hormonal yang dihasilkan. Mengembangkan daftar peristiwa disusun menurut besarnya kesulitan dalam penyesuaian. ${ }^{1}$

Hal yang menarik tentang skala perubahan hidup adalah skala ini menyatakan sekaligus peristiwa positif dan negatif. Perubahan yang terlalu banyak positif maupun negatif dapat membahayakan kesehatan. Proses persalinan adalah peristiwa besar dalam kehidupan individu yang akan mempengaruhi perubahan peran. Peran dan ketegangan peran dikatakan mempengaruhi perkembangan depresi terutama wanita. ${ }^{1}$

Peran baru merupakan krisis, yaitu gangguan internal yang ditimbulkan oleh peristiwa yang menegangkan atau ancaman yang dirasakan pada diri seseorang. Krisis mempunyai keterbatasan waktu dan konflik yang berat dan dapat merupakan periode peningkatan kerentanan, yang dapat menstimulasi pertumbuhan personal. Apa yang dilakukan seseorang terhadap krisis akan menentukan pertumbuhan atau organisasi bagi orang tersebut. ${ }^{1}$

Perubahan yang menimbulkan stess dan permasalahannya dalam kehidupan adalah normal. Untuk menghindari ketidakberdayaan kelelahan fisik, peningkatan emosional dan krisis psikologis maka manusia harus belajar menghadapi masalah dengan efektif melalui mekanisme adaptasi atau penyesuaian. ${ }^{2}$

Transisi peran situasi terjadi dengan bertambah atau berkurangnya anggota keluarga melalui kelahiran dan kematian. Transisi peran sehat sakit sebagai akibat pergeseran dari keadaan sehat ke keadaan sakit. Transisi ini mungkin dicetuskan oleh perubahan ukuran tubuh, bentuk penampilan, fungsi tubuh dan perubahan fisik berhubungan dengan pertumbuhan normal. ${ }^{1}$ Keluarga mempunyai peranan yang besar memberikan bantuan psikologis dan dukungan psikologis pada ibu. Keluarga banyak memberikan pertolongan dan bantuan pada ibu setelah persalinan. Semua yang diberikan lebih bersifat kebutuhan fisiologis karena pengetahuan akan ilmu perilaku dan psikologis itu sendiri sedikit atau mungkin tidak dimiliki oleh ibu dan keluarga. ${ }^{2}$

Ibu Post partum yang tidak berhasil menyesuaikan diri dengan peran barunya akan mengalami gangguan emosional seperti depresi pasca persalinan (DPP). Depresi pasca persalinan (DPP) adalah suatu depresi yang ditemukan pada perempuan setelah melahirkan, yang terjadi dalam kurun waktu 4 (empat) minggu. Kondisi ini dapat berlangsung hingga beberapa bulan. Faktor yang mempengaruhi terjadinya postpartum blues yang apabila tidak ditangani akan menjadikan Depresi Postpartum, secara internal adalah umur ibu ketika menikah dan hamil $<20$ tahun atau $>35$ tahun, pertama kali melahirkan/primipara, kesiapan menerima anggota keluarga baru termasuk pengetahuan atau ketrampilan merawat bayi dan pendidikan. Aspek eksternal adalah dukungan keluarga, dukungan suami, dan budaya. 
Kebiasaan masyarakat terkait persalinan, status ekonomi, informasi asuhan nifas dan riwayat asuhan nifas. ${ }^{3}$

Adaptasi psikologi terhadap kehamilan pada ibu primipara bersifat dramatis dan sering kali dianggap ringan. Waktu dan intensitas perubahan bervariasi antar berbagai sistem, tetapi semuanya dirancang guna memberi kesempatan kepada ibu untuk merawat janinnya dan mempersiapkan tubuhnya untuk persalinan..$^{2.4}$

Depresi postpartum diawali dari adanya kelelahan, gangguan tidur, adanya perasaan tidak mampu merawat bayi, adanya perasaan senang yang berlebihan akibat kelahiran bayi dan gejala stres. Depresi post partum merupakan salah satu bagian integral dari permasalahan gangguan jiwa yang terjadi pada ibu yang melahirkan. Dampak dari depresi ini dapat menurunkan semangat hidup, bahkan sampai pada tindakan ekstrem yaitu bunuh diri. ${ }^{2}$

Asuhan keperawatan komprehensif pada wanita post partum sama dengan asuhan keperawatan pada pasien lain meliputi aspek biopsikososial dan spiritual yang dapat menanggulangi keadaan darurat dan depresi dalam kesehatan jiwa. ${ }^{4}$

Strategi pengobatan non farmakologis berguna untuk wanita dengan gejala depresi ringan sampai sedang. Psikoterapi individu atau kelompok yang meliputi kognitif perilaku dan terapi interpersonal terbukti sangat efektif. Salah satu adalah cognitive behavior therapy (CBT) atau terapi perilaku kognitif yang merupakan salah satu bentuk konseling untuk membantu klien agar menjadi lebih sehat, memperoleh pengalaman yang memuaskan, dan dapat memenuhi gaya hidup tertentu, dengan memodifikasi pola pikir dan perilaku tertentu. ${ }^{2}$

Konseling perilaku kognitif terfokus pada kegiatan mengelola dan memonitor pola pikir klien sehingga mengurangi pikiran negatif dan mengubah isi pikiran agar diperoleh emosi yang lebih positif yang dilakukan dengan memberikan latihan relaksasi dan edukasi. Teknik relaksasi yang dilakukan untuk menurunkan kecemasan klien yang mengalami depresi post partum. Penanganan psikologis dalam bentuk edukasi pada ibu postpartum dapat mereduksi depresi postpartum dan meningkatkan respons positif. ${ }^{4}$

Upaya psikoedukasi pada ibu postpartum yang lazim ditemukan di Indonesia adalah hanya dalam bentuk saran dan nasehat agar ibu bayi dapat menjaga kesehatan diri dan bayinya, serta sabar terhadap segala konsekuensi yang dihadapinya, namun upaya tersebut tidak dilakukan secara komprehensif, dan tidak terprogram serta bukan merupakan bagian dari pelayanan persalinan seutuhnya, dan terkadang hanya pada kalangan tertentu saja, dan tenaga perawat tertentu saja. Keadaan tersebut dapat menjadi salah satu faktor risiko terhadap terjadinya depresi post partum pada ibu yang melahirkan. ${ }^{5}$

Penanganan psikologis dalam bentuk psikoedukasi pada ibu postpartum dapat mereduksi terjadinya depresi postpartum yang dilakukan oleh penyedia pelayanan kesehatan termasuk dokter, perawat dan bidan untuk mencari penyelesaian depresi postpartum. ${ }^{3}$

Psikoedukasi adalah suatu bentuk pendidikan ataupun pelatihan terhadap seseorang dengan gangguan psikiatri yang bertujuan untuk proses treatment dan rehabilitasi. Sasaran dari psikoedukasi adalah untuk mengembangkan dan meningkatkan penerimaan pasien terhadap penyakit ataupun gangguan yang ia alami, meningkatkan pertisipasi pasien dalam terapi, dan pengembangan coping mechanism ketika pasien menghadapi masalah yang berkaitan dengan penyakit tersebut. ${ }^{6}$

\section{METODE PENELITIAN}

Desain penelitian yang digunakan adalah one-group pretest-post test design yaitu kelompok subjek diobservasi sebelum dilakukan intervensi, kemudian diobservasi lagi setelah dilakukan intervensi. Ciri dari penelitian ini adalah mengungkapkan hubungan sebab akibat dengan cara melibatkan satu kelompok subjek. Pada penelitian ini adalah mendeskripsikan seberapa besarkah pengaruh pemberian psikoedukasi terhadap depresi postpartum. ${ }^{7}$ Populasi 
dalam penelitian ini berjumlah 24 ibu postpartum, pengambilan sampel menggunakan teknik total sampling yaitu seluruh dari populasi dijadikan sampel penelitian. ${ }^{7}$ Dengan demikian jumlah sampel pada penelitian ini adalah 24 responden. Analisa data univariat untuk mendapatkan gambaran depresi pada ibu postpartum primipara baik pre maupun post pelaksanaan psikoedukasi. Tingkat depresi pre dan post intervensi dianalisis dari intrumen Hamilton Depression Rating Scale (HDRS) dan diklasifikasikan. Analisa data bivariat dilakukan uji beda antara tingkat depresi pre intervensi psikoedukasi dengan tingkat depresi post intervensi psikoedukasi. Sebelum analisis bivariat dilakukan, peneliti terlebih dahulu melakukan uji normalitas dengan menggunakan Shapiro Wilk's, jika hasil uji normalitas data terdistribusi normal digunakan uji beda $T$-test, sedangkan data tidak terdistribusi normal menggunakan uji Wilcoxon.

\section{HASIL PENELITIAN}

\section{Tingkat Depresi Ibu Postpartum Primipara Sebelum Dilakukan Psikoedukasi}

Tabel 1. Distribusi Frekuensi Tingkat Depresi Ibu Postpartum Primipara Sebelum di Lakukan Psikoedukasi

\begin{tabular}{ccc}
\hline Tingkat Depresi Ibu Postpartum & Frekuensi & Persentase $(\%)$ \\
\hline Normal & 3 & 12,5 \\
Ringan & 12 & 50,0 \\
Sedang & 7 & 29,2 \\
Berat & 2 & 8,3 \\
Sangat Berat & 0 & 0 \\
\hline Total & 24 & 100 \\
\hline
\end{tabular}

Berdasarkan tabel 1 di atas menggambarkan bahwa dari 24 responden menunjukan bahwa sebagian besar responden mengalami tingkat depresi postpartum primipara ringan sebanyak 12 responden $(50.0 \%)$.

\section{Tingkat Depresi Ibu Postpartum Primipara Sesudah Dilakukan Psikoedukasi}

Tabel 2. Distribusi Frekuensi Tingkat Depresi Ibu Postpartum Primipara Sesudah di Lakukan Psikoedukasi

\begin{tabular}{ccc}
\hline Tingkat Depresi Ibu Postpartum & Frekuensi & Persentase $(\%)$ \\
\hline Normal & 10 & 41,7 \\
Ringan & 10 & 41,7 \\
Sedang & 2 & 8,3 \\
Berat & 2 & 8,3 \\
Sangat Berat & 0 & 0 \\
\hline Total & 24 & 100 \\
\hline
\end{tabular}

Berdasarkan tabel 2 di atas menggambarkan bahwa dari 24 responden menunjukkan bahwa sebagian besar responden mengalami tingkat depresi postpartum primipara ringan sebanyak 10 responden $(41.7 \%)$.

\section{Pengaruh Psikoedukasi Terhadap Depresi Postpartum primipara}

Berdasarkan tabel dibawah menunjukan bahwa nilai $p$ value pada uji beda (Paired Samples Test) tingkat depresi postpartum primipara sebelum dan sesudah dilakukan penyuluhan yaitu $\mathrm{p}$ value $=0.016$ sehingga dapat dinyatakan Ha diterima dan Ho ditolak . 
Tabel 3. Pengaruh Psikoedukasi Terhadap Depresi Postpartum primipara

\begin{tabular}{rcc}
\hline Variabel & Mean \pm SD & P Value \\
\hline Pre Test - Post Test & $3,458 \pm 6,507$ & 0,016
\end{tabular}

\section{PEMBAHASAN}

\section{Depresi Postpartum Primipara Sebelum dilakukan Psikoedukasi}

Berdasarkan hasil penelitian hampir sebagian besar responden (ibu postpartum) primipara mengalami depresi setelah melahirkan dari tingkat ringan hingga tingkat berat) hal ini dimungkinkan karena setelah melahirkan ada beberapa fase perubahan yang akan dialami ibu postpartum primipara fase tersebut diantaranya: Periode Taking In, Periode Taking Hold, Periode Letting Go. Sehingga pada masa setelah post partum primipara tidak semua ibu dapat menerima keadaan yang dialaminya sekarang sehingga dari hasil penelitian sebelum dilakukan psikoedukasi dapat disimpulkan bahwa 79,2\% ibu post partum primipara mengalami depresi. Hal ini sesuai dengan teori yang dikemukakan oleh Sulistyawati A bahwasanya pada masa postpartum primipara ibu akan mengalami fase mandiri. Pada fase ini tidak semua ibu Postpartum primipara mampu beradaptasi secara psikologis sehingga muncul gangguan mood yang berkepanjangan ditandai dengan adanya perasaan sedih, murung, cemas, panik, mudah marah, kelelahan, disertai gejala depresi seperti gangguan tidur dan selera makan, sulit berkonsentrasi, perasan tidak berharga, menyalahkan diri dan tidak mempunyai harapan untuk masa depan. Hal ini yang membuat sebagian besar ibu Postpartum primipara mengalami depresi karena pada masa/fase ini ibu postpartum primipara belum mampu beradaptasi secara psikologis terhadap perubahan yang terjadi pada dirinya baik perubahan secara fisik maupun perubahan secara psikis (perubahan peran menjadi seorang ibu).

\section{Depresi Postpartum primipara sesudah dilakukan psikoedukasi}

Berdasarkan hasil penelitian dapat digambarkan bahwa ada perubahan tingkat depresi yang dialami ibu postpartum setelah diberikan psikoedukasi hal ini dapat dibuktikan pada data univariat bahwa ibu dengan depresi ringan sebelum diberikan psikoedukasi berjumlah 12 orang setelah diberikan psikoedukasi berjumlah 10 orang. Hal ini sesuai dengan pendapat Matteson (2000), dukungan sosial, (social support) didefinisikan sebagai informasi verbal atau non verbal, saran, bantuan yang nyata atau tingkah laku yang diberikan oleh orang yang akrab dengan subjek di dalam lingkungan sosialnya atau yang berupa kehadiran dan hal-hal yang dapat memberikan keuntungan emosional atau berpengaruh pada tingkah laku penerimanya. Orang yang merasa mendapat dukungan sosial, secara emosional merasa lega karena diperhatikan, mendapat saran atau kesan yang menyenangkan pada dirinya.

\section{Pengaruh Psikoedukasi Dalam Mengatasi Depresi Postpartum primipara}

Berdasarkan tabel diatas menunjukan bahwa nilai $p$ value pada uji beda tingkat depresi postpartum primipara sebelum dan sesudah dilakukan penyuluhan yaitu $p$ value $=0.016$ atau Ho ditolak. Peningkatan rata-rata nilai post-test dikarenakan responden telah menerima "Psikoedukasi". yang meningkatkan kemampuan pengetahuan ibu postpartum primipara dalam menghadapi depresi. Psikoedukasi yang diberikan pada penelitian ini menunjukan hasil bermakna dibandingkan tidak diberi Psikoedukasi. Ini bertujuan untuk memberikan pengetahuan untuk merubah perilaku ibu postpartum dalam menghadapi depresi 
Analisa bivariat adalah analisa untuk melihat hasil antara tingkat depresi post partum primipara sebelum penyuluhan dan sesudah penyuluan kesehatan, dengan menggunakan uji paired $t$ test yang dilakukan untuk melihat perbedaan hasil. Berdasarkan penelitian yang telah dilakukan menunjukan nilai t hitung (hasil dari uji statistik) $>\mathrm{t}$ tabel (Nilai normal statistik) $(2.604>1.67866)$ atau $\mathrm{p}$ value $<\alpha(0.016<0.05)$ sehingga dapat terjadi penurunan tingkat depresi setelah dilakukan Psikoedukasi pada ibu postpartum primipara dengan depresi di Wilayah Kerja Puskesmas Plered Kabupaten Cirebon Tahun 2016.

Dari hasil olah data statistik didapatkan bahwa nilai $p$ value $=0.022$ sehingga dapat disimpulkan bahwa ada pengaruh yang signifikan antara kelompok yang diberikan psikoedukasi dengan kelompok yang tidak diberikan psikoedukasi. Hal ini sesuai dengan hasil penelitian Nazara (2006) dimana hasil uji statistik menunjukkan adanya perbedaan kejadian depresi Postpartum primipara antara kelompok kontrol dengan kelompok intervensi $\mathrm{p}<0,05$ ( $\mathrm{p}=0,001)$. Berdasarkan hasil uji statistik ini peneliti berkesimpulan bahwa ada perbedaan responden yang tidak mendapat intervensi psikoedukasi berpeluang mengalami depresi postpartum primipara sebanyak 2.064 kali dibandingkan dengan responden yang sudah mendapat intervensi psikoedukasi.

Dari hasil penelitian masih ada responden yang mengalami depresi sehingga peran serta tenaga kesehatan sangat diperlukan, dan sebaiknya dilakukan program pemberian penyuluhan kesehatan khususnya melalui psikoedukasi dengan memberikan informasi yang cukup tentang pencegahan depresi Postpartum primipara. Selain itu, pembagian booklet dilakukan pada saat pemeriksaan ANC berlangsung sehingga ibu prepartum dapat mencegah terjadinya depresi Postpartum primipara. Perlu dilakukan pelatihan bagi perawat yang memberikan pelayanan di tatanan pelayanan maternalitas agar mampu secara terampil melaksanakan intervensi psikoedukasi guna penanganan depresi postpartum primipara.

\section{SIMPULAN}

1. Depresi ibu post partum primipara sebelum diberikan Psikoedukasi adalah dari 24 responden menunjukan bahwa sebagian responden (50\%) mengalami tingkat depresi postpartum primipara ringan.

2. Depresi ibu postpartum primipara sesudah diberikan Psikoediukasi bahwa dari 24 responden menunjukan hampir setengah responden $(41.7 \%)$ mengalami tingkat depresi post partum primipara ringan

3. Terjadi penurunan tingkat depresi setelah dilakukan Psikoedukasi pada ibu postpartum primipara dengan depresi.

\section{SARAN}

1. Bagi Ibu Postpartum

Pada penelitian ini diharapkan dapat memberikan manfaat pada ibu post partum primipara untuk menambah wawasan dan pengetahuan tentang pengaruh psikoedukasi terhadap depresi post partum sehingga dapat mencegah kejadian depresi postpartum.

2. Bagi STIKes Cirebon

Diharapkan hasil penelitian ini dapat dijadikan sebagai bahan referensi dalam melakukan penelitian di STIKes Cirebon selanjutnya dan dapat bermanfaat untuk menambah wawasan dan pengetahuan tentang Pengaruh Psikoedukasi Terhadap Depresi Postpartum Primipara.

3. Bagi Peneliti

Hasil penelitian ini dapat menambah pengetahuan dan pengalaman dalam penelitian Pengaruh Psikoedukasi Terhadap Depresi Postpartum Primipara. 


\section{Bagi Perawat}

Hasil penelitian dapat menambah wacana dan bahan bacaan baru bagi ilmu keperawatan khususnya mengenai pengaruh psikoedukasi terhadap depresi postpartum.

\section{DAFTAR PUSTAKA}

1. Cahyo, Kusyogo. Kajian Adaptasi Sosial Psikologis Pada Ibu Setelah Melahirkan (Post Partum) Di Ruang Rawat Inap RSUD Kota Semarang. Jurnal. 2008. Diakses tanggal 10 Desember 2015, diunduh dari http://ejournal.undip.ac.id

2. Pilliter. Maternal and Child Health Nursing: Care of The Childbearing Family. Fourth Edition . Philadelphia: Lippincott Williams and Wilkins. 2003

3. Regina, Pudjibudojo, J. K dan Malinton, P. K. Hubungan Antara Depresi Postpartum Dengan Kepuasan Seksual Pada Ibu Primipara. Anima Indonesian Psychological Journal. 2001. Diakses tanggal 21 Desember 2015, diunduh dari http://www.google.co.id

4. Wheller L. Nurse-midwifery handbook: a practical guide to prenatal and postpartum care. Philadelphia: Lippincott; 2007

5. Wheller L. Nurse-midwifery handbook: a practical guide to prenatal and postpartum care. Philadelphia: Lippincott; 2007.

6. Walsh, Psycheducation In Mental Health. Chicago: Lyceum Books, Inc; 2010

7. Arikunto, Prosedur Penelitian Suatu Pendekatan Praktik. Jakarta: Rineka Cipta; 2011 